\title{
EFFECT OF SPANISH-LANGUAGE TRAINING MODULE ON TECHNICAL VOCABULARY ACQUISITION
}

A thesis presented to the faculty of the Graduate School of Western Carolina University in partial fulfillment of the requirements for the degree of Master of Science in Communication Sciences \& Disorders

By

Mary Claire Wofford

Director: Dr. K. Leigh Morrow-Odom

Assistant Professor of Communication Sciences and Disorders

Communication Sciences and Disorders Department

Committee Members: Dr. Bill Ogletree, Communication Sciences and Disorders

Prof. Mary Teslow, Health Sciences

March 2015 


\section{ACKNOWLEDGEMENTS}

I would like to especially thank my committee members Dr. Leigh Odom, Dr. Bill Ogletree, and Prof. Mary Teslow for their unwavering support and assistance in the completion of this project. Dr. Leigh Odom in particular has been a mentor, guide, and problem-solver throughout the process.

I would also like to thank Gloria Peña Rose, Summer McMurray, Teresa Eberle Davis, Dr. Lori Oxford, and Dr. Sue McPherson for their assistance with the Spanish-language module development, evaluation, and implementation, as well as the participants involved in the study for their patience, time, and creative solutions.

Importantly, to my family and friends I would also like to extend thanks for their encouragement during the course of this project. 


\section{TABLE OF CONTENTS}

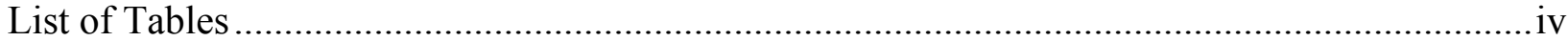

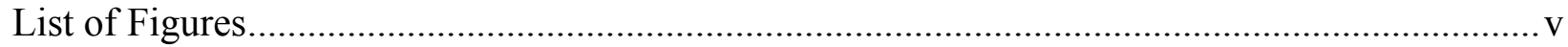

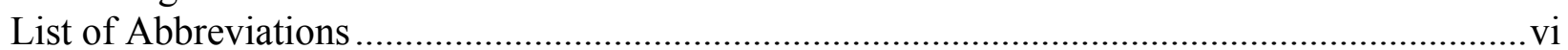

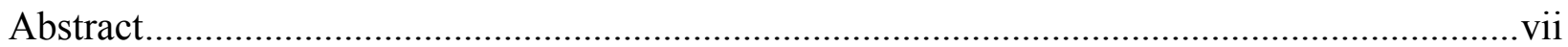

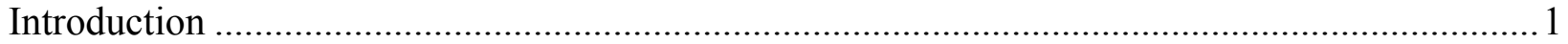

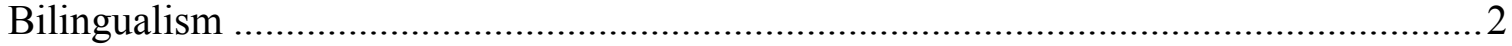

Bilingual Speech-Language Pathologists .................................................................... 3

Benefits of Bilingual Speech-Language Intervention ............................................... 4

Bilingual and Multicultural Academic Training ....................................................... 7

Profession-Specific Vocabulary Training of Students ................................................ 10

Development of Technical Vocabulary Acquisition Module ......................................... 13

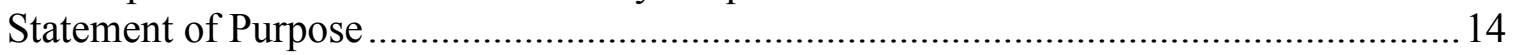

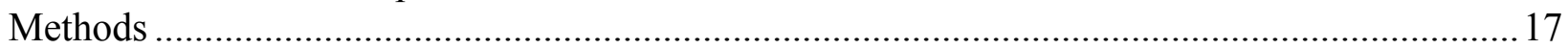

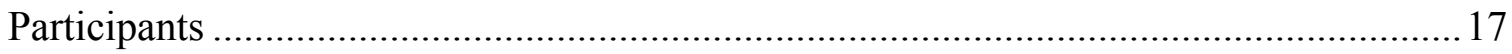

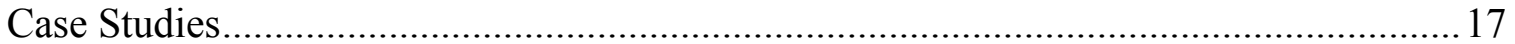

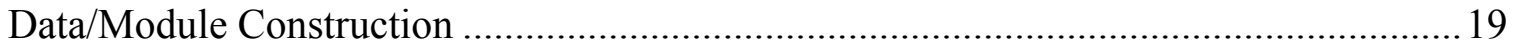

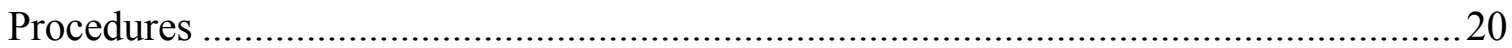

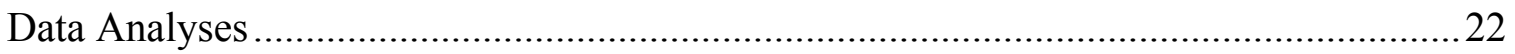

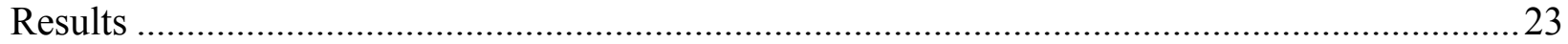

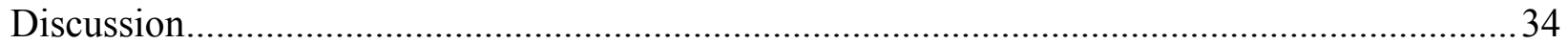

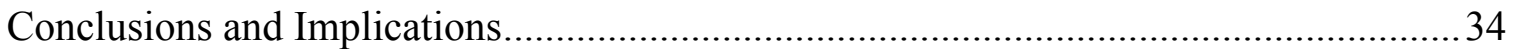

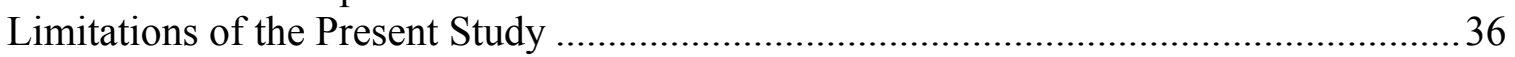

Directions for Future Study .................................................................................. 37

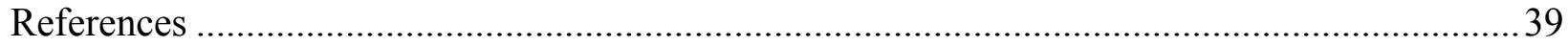

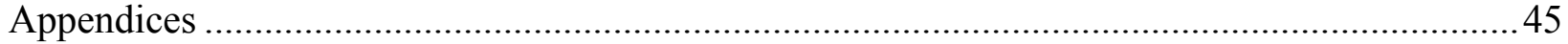

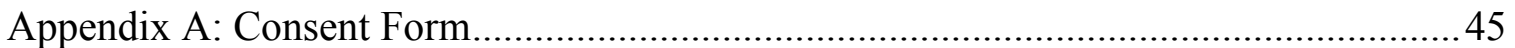

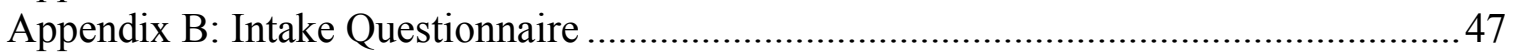

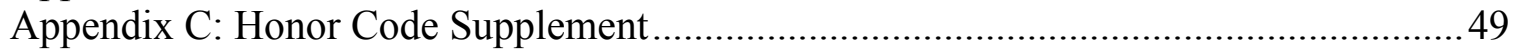

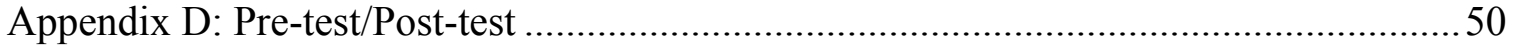

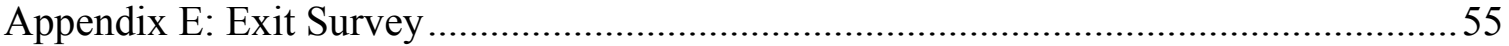




\section{LIST OF TABLES}

Table Page

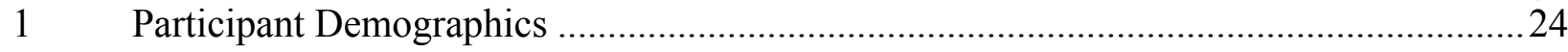

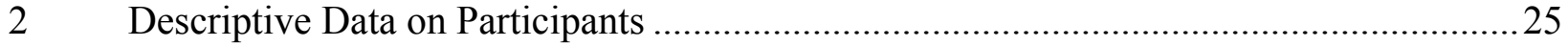

3 Total Participant Scores on Pre-test and Post-test ............................................................2 26

$4 \quad$ Descriptive Statistics and t-test Results for Pre-test and Post-test Scores..........................2 27

5 Descriptive Statistics and Wilcoxon Signed Rank Results for Confidence,

Preparedness, and Professional Identity ............................................................................2

6 Participant Comments on Most Helpful Aspects of Module,

Changes for Future Module, and Other Issues ..................................................................... 33 


\section{LIST OF FIGURES}

Table $\quad$ Page

$1 \quad$ Bar graph depicting participant score totals on pre-test and post-test...........................29

2 Bar graph depicting participant reports on confidence pre- and

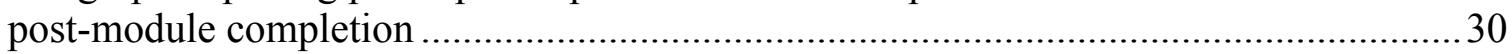

3 Bar graph depicting participant reports on preparedness pre- and

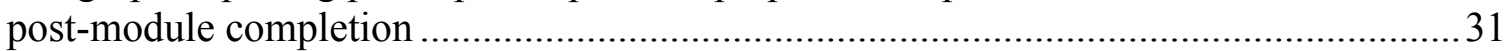

$4 \quad$ Bar graph depicting participant reports on professional identity pre-

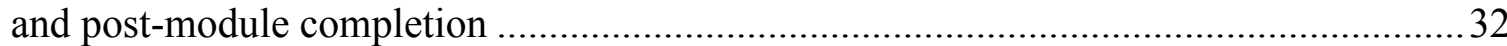




\section{LIST OF ABBREVIATIONS}

\begin{tabular}{|c|c|}
\hline BICS . & Basic Interpersonal Communicative Skills \\
\hline CALP & ..Cognitive Academic Language Proficiency \\
\hline LI .. & ..Language impairment \\
\hline $\mathrm{L} 1 \ldots$ & ..First Langua \\
\hline L2. & . Second Langua \\
\hline NC... & ...... North Caroli1 \\
\hline $\begin{array}{l}\text { SLA... } \\
\text { SI P }\end{array}$ & Second Language Acquisitic \\
\hline SLP ... & $\begin{array}{l}\text {...................... Speech-language Patholog } \\
\text { Statistical Package for the Social Scien }\end{array}$ \\
\hline
\end{tabular}




\begin{abstract}
EFFECT OF SPANISH-LANGUAGE TRAINING MODULE ON TECHNICAL VOCABULARY ACQUISITION

Claire Wofford, B.A.

Western Carolina University (March 2013)

Director: Dr. K. Leigh Morrow-Odom
\end{abstract}

This project created a module to be offered to Communication Sciences and Disorders (CSD) students interested in working with Spanish-speaking clients consisting of activities covering terminology and vocabulary relevant to the different areas of speech-language pathology in Spanish. In order to facilitate technical vocabulary acquisition, the module was designed using vocabulary-learning strategies from studies that have investigated effective means of acquiring second language (L2) vocabulary, including use of multiple strategies in combination and combination of intentional and incidental learning (Fan, 2003; Hummel, 2010; Lawson \& Hogben, 1996; Read, 2004). Participants were assessed in comprehension and production of the terms in four types of activities, including direct translations, cloze exercises using vocabulary terms in context, listening comprehension, and production of terms in context. All activities were completed through Blackboard at the student's own pace over the course of one semester. Data were collected on the effectiveness of the module in a pre-test/post-test comparison of scores, as well as Likert scale measurements of confidence, preparedness, and professional identity before and after module completion. Training activities replicated the tasks completed in the pre-test and post-test. Intermediate understanding of Spanish was required to participate in 
the module as evidenced by college-level coursework and cultural or personal experiences with the Spanish language. Upon completion of the module, students received a certificate to designate their participation in the course.

The study revealed changes in scores that represented significant gains made by all participants, as hypothesized and demonstrated in a paired t-test performed on totaled scores $(M$ $=22.4167, S D=11.4692, t(5)=4.788, p=0.005)$. The reported outcomes in confidence and preparedness also supported the alternate hypothesis as demonstrated in a Wilcoxon signed rank analysis $(Z=-2.232, p<.05 ; Z=-2.226, p<.05)$. However, changes in professional identity did not change as result of the training module $(z=-1.414, p>.05)$.

Participation in the module suggested overall positive results via gains made on the posttest and exit survey comments. Participants' reports of increased feelings of confidence and preparedness after module training coincided with findings in earlier research (Bender, Lawson, Harlan, \& Lopez, 2004; Kritikos, 2003; Mazor, Hampers, Chande, \& Krug, 2002). Participants did not report changes in professional identity with possible explanations being student status or the view of Spanish-language proficiency as a clinical tool, rather than defining professional quality. Limitations of the study included a small sample size and lack of a face-to-face component. 


\section{CHAPTER 1: INTRODUCTION}

In 2012, the Hispanic/Latino population reached 53 million nationally, representing a 50\% change since 2000 and six times its population since 1970 (Pew, 2014a). According to Pew, nearly two-thirds of the current Hispanic/Latino population comes from Mexico. Understandably, this makes Spanish the most-spoken second language in the United States (US) with 37.6 million speakers above the age of five years (Pew, 2013). For comparison, Pew identifies the next most common second language as Chinese with 2.8 million speakers nationally.

North Carolina (NC) in particular has seen a significant increase in the number of bilingual individuals in the state, as well as the number of monolingual Spanish-speaking individuals (U.S. Census, 2010). This increase in the number of Spanish-speaking persons living in the NC region would certainly lead to an increased need for bilingual providers in healthcare and educational settings. However, it remains to be seen if academic programs are producing professionals with the linguistic and cultural knowledge and skills to accommodate these needs in an ethical manner. Statistical data regarding current and future trends provide insights on the gravity of this matter.

According to the U.S. Census data collected in 2010, the population percentage of Hispanic/Latino individuals increased from $4.71 \%$ in 2000 to $8.4 \%$ in 2010 , an increase of $111 \%$. This amounts to 800,120 individuals and ranks $\mathrm{NC}$ as the sixth state in the nation with greatest Hispanic/Latino population growth, of which young families represent a large portion. Nearly $39 \%$ of all Hispanic/Latino individuals in NC are less than 17 years old, and $40 \%$ of all Hispanic/Latinos are between the ages of 18 and 39 (Pew, 2011). Compared to the Non- 
Hispanic population, $21 \%$ of all Non-Hispanics are less than 17 years old, and $28 \%$ of all NonHispanics are between the ages of 18 and 39. These percentages suggest an overall younger Hispanic/Latino population that may be entering or have already entered the school system. Importantly, $13 \%$ of K-12 students in NC are Hispanic/Latino (Pew, 2014).

\section{Bilingualism}

Merriam-Webster dictionary defines bilingualism as "able to speak and understand two languages" (Merriam-Webster, n.d.). While this general definition encompasses many individuals globally, the American Speech-Language-Hearing Association (ASHA) chooses to further elaborate citing research completed by Grosjean (1989) and Bialystok (2001). ASHA's position states that bilingualism "can be thought of as a continuum of language skills in which proficiency in any of the languages used may fluctuate over time and across social settings, conversational partners, and topics, among other variables" (ASHA, 2014a). Bialystok (2001) explains that bilingualism is not a "categorical variable," but rather a scale on which individuals range from complete unawareness of other languages to fluent use of two languages (p. 8).

With regards to Bialystok's proposed scale, the issue of proficiency arises as a common topic of debate in investigations of bilingualism. Researchers vary in their stringency when considering second language proficiency. Some stricter definitions require that a speaker possess native proficiency in order to be considered bilingual (Bloomfield, 1933). Others relax the requirement to include speakers who possess proficiency for functional tasks in the nonnative language (Haugen, 1953). Another definition specifies that lack of proficiency in modalities other than oral communication, such as reading and writing, should still be considered bilingual (Diebold, 1961). 
According to these varied definitions, bilinguals may differ greatly in their secondlanguage proficiency and the order of their language acquisition. They may be learning two languages simultaneously, such as a child raised in a bilingual family who uses both Spanish and English. This may result in equal proficiency in both languages, but varies depending on the contexts and opportunities in which the individual uses each language. They may be learning two languages sequentially, such is the case for many children in the US who speak Spanish first at home and then learn English at school. Bilinguals may vary in the use of their second language as well. A bilingual may be fluent orally in his/her second language and lack literacy skills in that second language, or vice versa.

For the purpose of this study, bilingual will be defined as any individual who possesses the capacity to communicate functionally in a language other than his/her native language. This does not stipulate native proficiency; rather it encompasses those individuals who are near-native or proficient speakers, as well as children who are in the process of acquiring their native language as well as a second language.

\section{Bilingual Speech-Language Pathologists}

Trends in bilingual service providers have also been the subject of research due to the expanding need for bilingual speech and language therapy nation-wide (Kritikos, 2003; Hammer et al., 2004; Stewart \& Gonzalez, 2002). ASHA (2014d) reported that 5\% of members nationally, including speech-language pathologists (SLPs) and audiologists, met the definition of bilingual service providers with 39\% of Hispanic/Latino descent and 61\% non-Hispanic/Latino. Of those who considered themselves bilingual service providers, 58\% were Spanish-language service providers. The same study observed prevalence of bilingual service providers in the state of NC where 111 bilingual SLPs and 10 bilingual audiologists represented $2.3 \%$ and $2.6 \%$ of all 
ASHA constituents within their respective professions. Of those 111 SLPs, 78 were denoted as Spanish-language service providers, representing 1.6\% of bilingual SLPs nationally, and three are Spanish-language audiologists representing $0.8 \%$ of the bilingual audiologists nationally. The discrepancy is evident. So few Spanish-speaking service providers cannot serve the continually growing need for clinicians who understand bilingual communication disorders to serve the expanding population of native Spanish speakers in the state. (It should be noted that this study was conducted in a survey format attached to ASHA member dues notices. The numbers reported do not reflect clinicians who chose not report themselves as bilingual, clinicians who are not members of ASHA, or monolingual clinicians who serve bilinguals on their caseload.)

Several ethical considerations exist for the monolingual and bilingual SLPs working with clients or patients who speak a language other than the clinician's native language. The ASHA Code of Ethics (2010) binds SLPs to a scope of practice that provides "culturally and linguistically appropriate services" to clients and patients without discrimination (ASHA, 2007, p.3). However, the Code of Ethics also binds SLPs to provide services within "their level of education, training, and experience”, including establishing and maintaining language proficiency. SLPs face the dilemma of serving all individuals without discrimination while being able to provide individualized, appropriate services given their own limited knowledge of the client's native language.

\section{Benefits of Bilingual Speech-Language Intervention}

When SLPs evaluate a bilingual client or patient, they should attempt to assess the individual's abilities in any language that the individual uses for communication, including the native language (L1) and the second language (L2) (ASHA, 2014a). This will help to determine 
if the individual is truly experiencing a language disorder or simply making errors due to a language difference which results from the natural processes that occur in bilingualism. According to ASHA, such processes include interference or transfer of rules from L1 to L2, silent periods; code-switching language loss or attrition; and accent and/or dialect. Identifying what characterizes a bilingual person's language proficiency requires recognizing the phenomena of bilingual development as well as the deficits that stem from language impairment. ASHA also stipulates that culturally- and linguistically-appropriate adaptations of evaluation materials should be used when available to avoid norm-based comparisons that may be biased due to sampling of other cultural groups.

Aside from accurately portraying ability and need and comparing fairly to similar populations, evaluating and treating in the L1 of a child aids in social and familial development. Bilingual intervention has been shown to be more effective in certain aspects of treatment than providing services exclusively in the L2 of the child (Kohnert, Yim, Nett, Kan, \& Duran, 2005; Pham, Kohnert \& Mann, 2011). Kohnert and colleagues (2005) reviewed the literature discussing the importance of providing services in the home language if it is not the majority language for reasons of social, emotional, and cognitive importance in child development. The authors suggest training other individuals, such as family members, paraprofessionals, and other communicative partners, such as peers or siblings, in the child's community to administer techniques that facilitate home language development. While the authors concede that none of these options is ideal, they discuss that at least some intervention the home language is beneficial in the absence of a bilingual SLP. Failing to provide home language support in an attempt to expedite the learning of the majority language may result in isolation of the child from the family and loss of important unifying cultural concepts. 
To elaborate upon the misconception of language confusion, some SLPs suggest that parents and caregivers choose one language in which to communicate with the child in the home to avoid confusing the child with language impairment (LI). However, research shows that children, including those with language impairments, who are exposed to bilingual environments are able to perform as well as monolingual children and are able to make gains despite their language impairments (Kay-Raining Bird et al., 2005; Paradis, Crago, Genesee, \& Rice, 2003; Pham, Kohnert, \& Mann, 2011). Pham, Kohnert, and Mann (2011) presented a single-subject case study of a Vietnamese-English bilingual child with moderate-severe language delays. The researcher was fluent in Vietnamese and compared bilingual intervention with English-only intervention in four different receptive language tasks. Results demonstrated increased attention to task in the bilingual intervention, which negates a common misconception that bilingual children are confused by bilingual intervention. Ultimately equal gains were demonstrated in both bilingual and English-only intervention, and the bilingual intervention allowed the child to continue growth in the L1. Teachers and parents both noted an increase in social communication post-treatment. The authors discuss the implications of client-clinician linguistic mismatch, which is a common phenomenon in the workplace due to few bilingual providers. To compensate for lack of linguistic knowledge in a client's L1, the researchers discuss strategies including collaboration with bilingual individuals, creation of bilingual therapeutic materials, technology, and continual assessment in both languages.

Furthermore, research has shown that Spanish-language intervention, or at least bilingual intervention, is preferred in school-aged children with language impairment whose academic language is English, or L2, to avoid language attrition and plateauing in the native language (Ebert, Kohnert, Pham, Disher, \& Payesteh, 2014). Children in a bilingual treatment group in 
this study experienced gains in vocabulary in both Spanish and English, with more noticeable gains being made in English. This is possibly due to the greater educational setting being English-centric and due to cross-linguistic transfer of concepts covered in the bilingual treatment. The authors explain that gains in the native language in school-aged children are harder to obtain due to a great amount of linguistic input being provided in English in the school. Therefore, therapy for children with language impairment should ideally incorporate the native language in order to preserve the L1.

\section{Bilingual and Multicultural Academic Training}

The importance of cultural competence training cannot be understated as culture and language development are inextricably linked. However, cultural competence training often does not include language-specific training (Matelliano \& Stone, 2014; Stone et al., 2013). Training opportunities ideally should be presented clearly as addressing a person's linguistic knowledge of a second language or the cultural competence of a population. It would stand to reason that there is value in providing development in both areas for increased clinical effectiveness when working with diverse populations. Often low levels of cultural awareness and lack of linguistic proficiency coexist, and increasing training opportunities in both areas is warranted (Baig et al., 2014).

As an example of a communication disorders course in multicultural populations, ASHA (2014c) provides a sample syllabus suggesting that the course offers a comprehensive perspective of many different culturally- and linguistically-diverse populations. While this course would provide valuable insight for SLPs involved in the evaluation and intervention of culturally-diverse populations, it may not suffice for an SLP serving a caseload with many Hispanic/Latino clients because it does not provide ample time to cover the necessary skills and 
background information to communicate in the native language with the client even partially. Further training and/or coursework would be required to master the topics pertinent to practice with Hispanic/Latino populations effectively in the Spanish language. To further explain, the goal of the course is not linguistic in nature, but rather observes behaviors, practices, and history, among other societal aspects of the community, which all shape communication. Therefore, the course does not address or improve the linguistic competence of the clinician via direct study of the languages mentioned in the syllabus. This illustrates the difference between multicultural training and bilingual training as separate, yet equally important facets of clinician development.

Another study observed healthcare providers' Spanish-language abilities related to diabetes education and management (Baig et al., 2014). The researchers surveyed more than 600 healthcare providers in the Midwestern US. The survey demonstrated that self-reported Spanishlanguage proficiency and cultural competence scores both fell below what was needed in the region to address needs of bilingual patients, according to the authors. Sixty-eight percent of participants reported a low level of Spanish-language proficiency, while $78 \%$ of participant reported either a low or moderate level of cultural awareness. Of providers who reported that at least $76 \%$ of their patients were Latino, $27 \%$ had never received cultural competency training nor had access to training. Interestingly, results demonstrated that even among health providers of Latino descent, about $8 \%$ of participants, scores in cultural competence and linguistic proficiency were not always high, which according to the researcher is a common false assumption made about Latino providers. The authors suggest that cultural competency programs and courses may need to make improvements in content to address the lower scores of cultural awareness among providers who had received cultural competency training. Furthermore, the researchers described a need to improve access to training for providers working with mostly Latino patients. 
Another example of service provider training focusing on improving linguistic proficiency comes from the medical field (Mazor, Hampers, Chande, \& Krug, 2002). In this study, pediatric emergency physicians participated in an intensive, 10-week medical Spanish course, including mock clinical scenarios and testing of linguistic knowledge. The course did include some elements of cultural competence training, but focused primarily on developing comprehension and production skills that would aid in taking medical history and facilitating clinical interaction. Results from a survey of Spanish-speaking families served by the pediatricians in the mock clinical sessions revealed increased patient satisfaction, as evidenced by higher likelihood to strongly agree post-training that the physician was respectful, concerned, attentive, and comforting in the clinical encounter. The study also led to a decreased reliance on interpreters in practice. The researchers commented that interpreters might still be required in complicated cases, but that in the clinical encounters trained, the cases were relatively uncomplicated and could therefore be addressed immediately by the physician with a likely immediate impact on patient compliance and follow-up.

Similarly, a study from Bender, Lawson, Harlan, and Lopez (2004) illustrated numerous other benefits gained from Spanish-language training to promote bilingualism in other allied healthcare professions. In a 2-week or 4-week immersion workshop focusing on medical Spanish for a variety of healthcare professionals in NC, participants reported impact in several areas of practice in structured interviews one year after completion of the course. The participants described many benefits including improved comprehension, greater confidence in speaking, improved grammar, improved cultural proficiency, and gains in vocabulary. The program, which followed a Berlitz language-learning model focusing on auditory learning, was designed to provide health-related vocabulary, functional grammar, cultural awareness training, 
and structured opportunities to practice the skills. While the interviews were largely positive in reviewing the course, the participants reported it was difficult to make adjustments in order to participate in a course of 2- or 4-week duration.

The literature demonstrates the benefits of increased language proficiency are established in more effective clinician-patient interaction from both parties' perspectives (Bender, Lawson, Harlan, \& Lopez, 2004; Mazor, Hampers, Chande, \& Krug, 2002). While the benefits of cultural competency training are equally important, linguistic training is sometimes not included with cultural competency training (ASHA, 2014c). Furthermore, to assume that linguistic competence and cultural competence go hand in hand is often a mistake as the content provided in each type of training is distinct (Baig et al., 2014). Though these concepts are often presented as a total package, separating language proficiency from the cultural component for training purposes may prove to be beneficial.

For the purposes of this study, bilingual training initiatives refer to the study of a second language in order to develop skills required to communicate competently with diverse populations. Multicultural training initiatives refer to development of cultural competence and sensitivity through study of communication styles, practices, behaviors, biases, and beliefs.

\section{Profession-Specific Vocabulary Training of Students}

While there is a marked increase in the availability of coursework and continuing education pertaining to multicultural populations and cultural competence in the field of speechlanguage pathology, language-specific training is kept separate and often is underrepresented as a requirement for true cultural competence. The university setting provides a logical opportunity to offer training to graduate students given the resources available to students. The evidence supports such training efforts promoting multicultural awareness and sensitivity in the profession 
(Stewart \& Gonzalez, 2002). Stewart and Gonzalez surveyed master's programs in speechlanguage pathology across the country and argued for integrating content pertaining to culturallydiverse populations across the existing curriculum for a fuller understanding of those populations' issues. The benefit of integrating concepts related to culturally-competent evaluation and intervention relates to the self-efficacy, or the confidence in one's own skills, with which bilingual SLPs practice.

Though there is little research on SLP actual practices or preferred language when evaluating and treating Hispanic/Latino populations in NC, nationally there is evidence that suggests training students and clinicians on topics related to cultural diversity prepares them to be more confident, competent SLPs. Logically, language-specific experience is found to increase levels of clinician confidence in addition to fostering more efficient clinician-client communication (Hammer et al., 2004; Kritikos, 2003; Stewart \& Gonzalez, 2002). Kritikos (2003) surveyed monolingual and bilingual SLPs from across the country and found that bilingual SLPs (i.e., those who had cultural experience with a second language and those who pursued a second language through academic study) had greater personal confidence in their skills when assessing speakers of other languages. This study also demonstrated the implications in practice as lack of training often leads to under-referral of bilingual children who are in need of services. According to Kritikos (2003), approximately $40 \%$ of monolinguals, culturally experienced bilinguals, and bilinguals gaining proficiency through academic study exclusively reported that they would be more conservative in referring a bilingual child for language treatment compared to referring a monolingual child due to lack of confidence in bilingual assessment. 
There are numerous accounts of other healthcare disciplines are responding to the need for Spanish-speaking providers with courses furthering students' understanding of Spanishlanguage terminology (Bender, Lawson, Harlan, \& Lopez, 2004; Bloom, Timmerman, \& Sands, 2006; Cobb, Perez-Brown, and Owens, 2011; Dinkins \& Scolaro, 2012; Mazor, Hampers, Chande, \& Krug, 2002). Mental health professionals have been one group of healthcare professionals that has used "ethnic matching" to pair Hispanic/Latino patients with bilingual providers (Castaño, Biever, González, \& Anderson, 2007; Verdinelli \& Biever, 2009). However, a shortage of bilingual therapists limits services that can be effectively provided. Furthermore, bilingual therapists claim that they do not feel properly trained to provide services in Spanish. While $93 \%$ of bilingual mental health practitioners reported they were conversationally fluent in Spanish, their proficiency was described as "context dependent", explained by the therapists in many of their reports that expressed struggle translating concepts and technical language in the therapeutic process with their Spanish-speaking patients (Castaño et al., 2007). The required language was therefore often presented with a lower level of proficiency.

A theoretical reason for lack of confidence and clinician proficiency comes from the field of second language acquisition. Cummins (1979) distinguished between conversational-level vocabulary and more specialized, technical vocabulary in his model for second-language education. Basic interpersonal communicative skills (BICS) are the basic conversational fluency skills usually obtained in two years after first exposure to a second language. Cognitive academic language proficiency (CALP) is the higher-level language required in academic and specialized topics that requires at least five years of study to begin to master. Cummins' theory resonates with bilingual healthcare providers seeking further training in specialized vocabulary for use in practice. Bilingual caregivers may have already established BICS through lifelong 
use, study, or other cultural experiences, yet they are lacking training in the higher-level terminology for more efficient, effective communication of health concepts to patients.

\section{Development of Technical Vocabulary Acquisition Module}

In order to create an effective model for technical vocabulary acquisition, the designer of the module turned to the field of Second Language Acquisition (SLA) to discover successful vocabulary-learning strategies for students. Numerous studies have investigated the most effective strategies to acquire L2 vocabulary (Fan, 2003; Hummel, 2010; Lawson \& Hogben, 1996).

Lawson and Hogben (1996) showed in their study that successful vocabulary acquisition in advanced learners consisted of using a set of consistent strategies to acquire new vocabulary. In general, students did not utilize strategies focusing on the physical features of targets, such as spelling, word classification, and suffix use, when learning new vocabulary. Rather, successful students reported that they used multiple repetitions, reading lists of related words similar to a dictionary entry, and simple word rehearsal as their primary strategies for acquisition.

Successful learners employed more diverse learning strategies, whereas less successful learners used fewer strategies in combination.

In a study of adult Cantonese speakers learning English, Fan (2003) administered a selfreport survey to identify strategies for L2 vocabulary acquisition in the most successful learners. Repetition and association strategies were found to be used by less-proficient learners, and Fan suggests that mechanical strategies may be a less-preferred means of acquisition. Moreproficient learners tended to use more types of vocabulary strategies than less-proficient learners, including reading sources outside of classwork, referring to the dictionary, guessing, and using context clues found within texts, among other strategies. 
The most successful learners in Fan's (2003) study referred to rediscovering learned words in context, which is a form of incidental learning. The successful learners' strategies correspond with Fan's assertion that "learners should be provided with as many chances as possible to re-encounter the words newly learned for their acquisition" (p.234). Read (2004) noted that incidental learning is responsible for some learning, but intentional vocabulary study is also necessary for L2 vocabulary acquisition, suggesting that combinations of strategies would maximize learning outcomes.

Hummel (2010) posited that a higher-level cognitive function, such as translation of target vocabulary, would result in higher acquisition rates among intermediate learners, but found acquisition to be higher in a low-level cognitive activity: rote-copying. She suggested target translation combined with a copying activity as a possible classroom application, tapping higher- and lower-level processing.

These studies (Fan, 2003; Hummel, 2010; Lawson \& Hogben, 1996) posed clinical questions pertaining to whether vocabulary acquisition was enhanced by using higher-level processing activities, yet no study significantly showed that activities requiring more complex activity were necessary for acquisition, though all studies demonstrated learning occurs in both conditions. Both Fan (2003) and Lawson and Hogben (1996) emphasized breadth of resources, rather than depth of understanding, as distinguishing characteristics of successful learners.

\section{Statement of Purpose}

The census data from recent years clearly demonstrate a significant increase in Spanishspeaking monolinguals and bilinguals in the US, and this will correlate with increased requests for speech and language services in educational and healthcare settings. It has also been suggested that there are numerous benefits of multicultural and bilingual training, including more 
effective evaluation and treatment outcomes when providing services to culturally- and linguistically-diverse clients. Considering speech-language pathology specifically, the need for language-specific training programs is evident, and the academic setting may be the most logical setting for such training given the availability of expertise and teaching technologies. The purpose of this study is to determine the effectiveness of an online Spanish-language training program for students in a speech-language pathology graduate program. Specifically, participants will receive language training via an online module of Spanish-language terminology and vocabulary related to the field of speech-language pathology.

This study seeks to answer the following questions.

Question 1: Will graduate students demonstrate quantitative gains in technical vocabulary in Spanish in a focused study of terminology related to speech-language pathology?

Hypotheses

$\mathrm{H}_{0}$ : Students will not demonstrate change in technical vocabulary ability as measured on a vocabulary exam after participating in a Spanish-language training module.

$\mathrm{H}_{1}$ : Students will demonstrate gains in technical vocabulary pertaining to speechlanguage pathology as measured on a vocabulary exam after participating in a Spanishlanguage training module. .

Question 2: Will graduate students demonstrate gains in confidence, preparedness, and professional identity from completion of a technical Spanish-language vocabulary module? Hypotheses 
$\mathrm{H}_{0}$ : Students will not express changes in confidence, preparedness, and professional identity on post-completion interviews after completion of a technical vocabulary training module.

$\mathrm{H}_{1}$ : Students will express positive changes in confidence, preparedness, and professional identity on post-completion interviews after completion of a technical vocabulary training module 


\section{CHAPTER 2: METHODS}

\section{Participants}

Six graduate students from within the speech-language pathology training program at Western Carolina University participated in this study, approved by the Western Carolina University Institutional Review Board. After completing the consent form (Appendix A), participants were asked to complete an intake questionnaire (Appendix B) to document their academic experiences (e.g., coursework) as well as cultural experiences (e.g., study abroad, employment) in Spanish-speaking countries or with Spanish-speaking family members. Through this questionnaire, it was determined that all participants had at least some experience in both academic and cultural pursuits of the Spanish language. However, for the purposes of this study, the manner and environment in which the language proficiency was obtained, whether academic of cultural, was not considered as a qualifying condition.

\section{Case Studies}

\section{Participant A}

Participant $\mathrm{A}$ is a 25-year-old female and third year graduate student who reported that a portion of her early academic years were spent in a Central American Spanish-speaking country. Her highest level of coursework completed in Spanish was at the advanced undergraduate level. She also identified cultural experiences including a Spanish-speaking family member, having spent extended time living in a Spanish-speaking country, and working in a setting that required Spanish to be spoken with coworkers. Her motivation in completing this module was to continue advancing her use of the language and to maintain her Spanish-language proficiency.

\section{Participant B}


Participant B is a 25-year-old female and first year graduate student who reported that she completed an undergraduate degree in Spanish language and literature. She lived in three different Spanish-speaking countries both for study abroad as well as for work during a period of four years. She also reported working in a setting that required Spanish spoken between coworkers. She reported that her motivation for completing the module was her interest in working as a bilingual SLP.

\section{Participant C}

Participant $\mathrm{C}$ is a 31-year-old female and first year graduate student who reported completion of advanced undergraduate coursework. She also described her cultural experiences to include living, studying, and working in a Spanish-speaking country for four or more years. She also has a Spanish-speaking spouse. She reported that her motivation for completing the module was to prepare herself to work as a bilingual SLP.

\section{Participant D}

Participant D is a 25-year-old male and third-year graduate student who reported academic experience including a minor in Spanish and a 3-month study abroad program. His cultural experiences included a Spanish-speaking family member and 6-months spent living in a Spanish-speaking country. His primary motivation for completing the module was to advance his Spanish-speaking skills.

\section{Participant E}

Participant E is a 29-year-old male and first-year graduate student who reported intermediate-level coursework in Spanish during his four years of college. He also reported cultural experiences, including a Spanish-speaking family member and a 6-month study abroad 
experience in a Spanish-speaking country. He reported his motivation for completing the module was to improve his Spanish in the context of SLP services provided to clients or parents.

\section{Participant F}

Participant F is a 25-year-old female and second-year graduate student who reported an undergraduate major including advanced Spanish coursework, as well as study abroad experience in a Spanish-speaking country a period of nearly six months. Her primary motivation for completing the module as per her report was to determine her current Spanish proficiency and to improve future marketability as a bilingual SLP.

\section{Data/Module Construction}

The module was developed with the objective of providing myriad opportunities for target acquisition and offering many opportunities for targets to be recalled in context, combining incidental and intentional learning strategies. Both receptive and expressive tasks were included, and all training items were tasks that mirrored the pre- and post-test items (Appendix C).

The four different training and assessment tasks were as follows. First, a direct written expressive translation task required participants to provide the Spanish-language equivalent of an English word. Second, a receptive cloze procedure was presented in which the participant was asked to choose the best word to complete a sentence from a field of four options. Third, a receptive listening exercise required the participant to watch a short video and answer questions pertaining to the target vocabulary contained in the video from a multiple choice field of four options. Fourth, an oral expressive task required the participant to submit an audio recording in which he/she was asked to translate a sentence or series of sentences containing the target vocabulary items. The participants completed each set of exercises for four areas within speech- 
language pathology: articulation and phonological processes; fluency; voice and resonance; and language. Participants completed each series of activities for only one area of speech-language pathology at a time before moving to the next set of vocabulary. For example, participants completed all of the activities for articulation before being allowed to move to the set of vocabulary and training activities in the area of fluency.

The target vocabulary and some of the training and assessment exercises were primarily taken from Spanish Phrasing for SLP's [sic] (Esckelson \& Morales, 1998). This handbook for SLPs contains terminology and vocabulary in the areas of articulation/phonology, hearing, language, stuttering, and voice disorders. Some terms were added or updated using newer resources including medical dictionaries, online glossaries, and translated patient resources.

The pre-test and post-test were identical 33 -item assessments. Of the 33 items, 28 were automatically corrected using the Blackboard interface. Five of the 33 items required review by an evaluator. Of the automatically scored items, the direct translation items required the exact orthographic representation in Spanish, including accents and other special characters, in order to be counted as correct. Items from the test at times required more than one target vocabulary item. For example, in the audio file response items, participants were required to translate between two and five target vocabulary words in the context of likely patient-SLP dialogue. Participants were scored on the presence or absence of the vocabulary item in their response.

Two evaluators not involved with the development of module were asked to score the five oral expressive items in both the pre- and post-tests as a measure of reliability. Both had high levels of proficiency in Spanish and were provided with the same training information for submitting scores in Blackboard.

\section{Procedures}


Recruitment for this study was conducted exclusively within the Communication Sciences and Disorders department at Western Carolina University. Each participant read and completed an informed consent form for participation that was approved by the Institutional Review Board of Western Carolina University. In a group meeting, all questions posed by participants were answered before consenting to participate. Participants also consented to an honor code agreeing to refrain from using external aids on the pre- and post-tests and from studying outside of the module activities. This attempted to prevent students from referring to module contents during testing and to isolate results as the effects of module activities, rather than other confounding factors such as supplemental study activity. The honor code, which was provided to participants along with the consent form before beginning the module, can be seen in Appendix D.

Students were allowed the duration of a semester to complete the module on their own timeline. All students were required to complete the pre-test by the midpoint of the semester to avoid large discrepancies of participants' time between pre- and post-test completion. Upon completion of the pre-test, the first module section opened, and upon completion of the final activity in each module, the following module section opened. This was designed to ensure that participants completed all module activities before the final assessment.

Participants also completed an exit survey (Appendix E) upon completion of the module to assess gains in different areas of performance. This was a 10-item survey consisting of three open-ended questions and seven items using a Likert scale. Six of the seven Likert scale items compare student perceptions of confidence, preparedness, and professional identity before and after completion of the module. In this study, the following definitions applied. Confidence was defined in this study as the feeling of self-assurance that comes from being aware of one's own 
abilities or skills. Preparedness was defined as the quality or state of being prepared, and professional identity was defined as the constant characteristic or quality shaping an individual's professional activities. The seventh Likert scale addresses overall effectiveness as perceived by the student. The open-ended questions provided students a venue to report what they found most helpful in the module, what suggestions they had for improvements, and any other comments pertaining to the module.

\section{Data Analyses}

Categorical data collected included the age of each participant, as well as standing within the department. Non-categorical information including academic coursework and cultural experience relevant to the topic was collected, along with other open-ended responses pertaining to motivation for completing the module. A paired t-test analysis was conducted on the total scores to evaluate change after module completion. Separate paired t-tests were conducted on Likert scale scores to evaluate the impact of the module on participants' confidence, preparedness, and professional identity. Likert scales ranged from 1 to 5 , or "Not at all confident" to "Extremely confident" for each item. All descriptive data and paired t-test analyses were conducted using IBM Statistical Package for the Social Sciences (SPSS). Alpha was set at .05 for all tests. Mean difference scores and $95 \%$ confidence intervals were used as effect sizes. 


\section{CHAPTER 3: RESULTS}

Participant demographics and descriptive data are presented in Table 1 and Table 2, respectively. Mean age of participants was $M=26.67, S D=2.66$. Participants' raw scores on the pre-test and post-test are reported in Table 3. A paired t-test analysis of pre-test and post-test scores, seen in Table 4, was conducted to observe the changes in participants' scores after module completion. Effects of the module were found to be significant for totaled scores, $(M=$ 22.4167, $S D=11.4692), t(5)=4.788, p=0.005$, with all participants increasing their scores in the post-test. Thus a large effect size was noted $(M D=22.4)$. This finding indicates that the training program improved participants' total scores via the vocabulary assessment instrument.

A second analysis observed before and after Likert scale rankings in the areas of confidence, preparedness, and professional identity, seen in Table 5. A Wilcoxon signed rank analysis demonstrated a significant difference in the scores for confidence, $Z=-2.232, p<.05$, with all participants ranking increased confidence when working with Spanish-speaking patients or clients after module completion. There was also a significant difference in the scores for preparedness for work with Spanish-speaking patients or clients, $Z=-2.226, p<.05$, for all participants. There was no difference in the development of professional identity for participants after module completion, $z=-1.414, p>.05$. 
Table 1

Participant Demographics

\begin{tabular}{llll}
\hline Participant & Age & Sex & $\begin{array}{l}\text { Standing in } \\
\text { Department }\end{array}$ \\
\hline A & 25 & Female & $3^{\text {rd }}$ year \\
B & 25 & Female & $1^{\text {st }}$ year \\
C & 31 & Female & $1^{\text {st }}$ year \\
D & 25 & Male & $3^{\text {rd }}$ year \\
E & 29 & Male & $1^{\text {st }}$ year \\
F & 25 & Female & $2^{\text {nd }}$ year \\
\hline
\end{tabular}


Table 2

Descriptive Data on Participants

\begin{tabular}{|c|c|c|c|}
\hline Participant & $\begin{array}{l}\text { Academic } \\
\text { Experience }\end{array}$ & Cultural Experience & Motivation \\
\hline $\mathrm{A}$ & $\begin{array}{l}\text { Advanced } \\
\text { undergraduate } \\
\text { courses }\end{array}$ & $\begin{array}{l}\text { Spanish-speaking } \\
\text { family member; } \\
\text { lived and worked in } \\
\text { Spanish-speaking } \\
\text { country }\end{array}$ & $\begin{array}{l}\text { To advance, } \\
\text { maintain language } \\
\text { skills }\end{array}$ \\
\hline $\mathrm{B}$ & $\begin{array}{l}\text { Undergraduate } \\
\text { major in Spanish }\end{array}$ & $\begin{array}{l}\text { Lived and worked in } \\
\text { Spanish-speaking } \\
\text { country }\end{array}$ & $\begin{array}{l}\text { Interested in } \\
\text { bilingual SLP work }\end{array}$ \\
\hline $\mathrm{C}$ & $\begin{array}{l}\text { Advanced } \\
\text { undergraduate } \\
\text { courses }\end{array}$ & $\begin{array}{l}\text { Lived, studied, } \\
\text { worked in Spanish- } \\
\text { speaking country; } \\
\text { Spanish-speaking } \\
\text { family member }\end{array}$ & $\begin{array}{l}\text { To prepare self to } \\
\text { work as bilingual } \\
\text { SLP }\end{array}$ \\
\hline $\mathrm{D}$ & $\begin{array}{l}\text { Undergraduate } \\
\text { minor in Spanish }\end{array}$ & $\begin{array}{l}\text { Spanish-speaking } \\
\text { family member; } \\
\text { lived in Spanish- } \\
\text { speaking country }\end{array}$ & $\begin{array}{l}\text { To advance Spanish } \\
\text { speaking skills }\end{array}$ \\
\hline $\mathrm{E}$ & $\begin{array}{l}\text { Intermediate level } \\
\text { coursework }\end{array}$ & $\begin{array}{l}\text { Spanish-speaking } \\
\text { family member; } \\
\text { studied abroad in } \\
\text { Spanish-speaking } \\
\text { country }\end{array}$ & $\begin{array}{l}\text { To improve Spanish } \\
\text { for SLP services }\end{array}$ \\
\hline $\mathrm{F}$ & $\begin{array}{l}\text { Undergraduate } \\
\text { major in Spanish }\end{array}$ & $\begin{array}{l}\text { Studied abroad in } \\
\text { Spanish-speaking } \\
\text { country }\end{array}$ & $\begin{array}{l}\text { To determine } \\
\text { current Spanish } \\
\text { proficiency; to } \\
\text { improve future } \\
\text { marketability as } \\
\text { bilingual SLP }\end{array}$ \\
\hline
\end{tabular}


Table 3

Total Participant Scores on Pre-test and Post-test

\begin{tabular}{lll}
\hline Participant & Pre-test & Post-test \\
\hline A & 18.5 & 45 \\
B & 30 & 42 \\
C & 36.5 & 47.5 \\
D & 22 & 36.5 \\
E & 17 & 54.5 \\
F & 23 & 56 \\
\hline
\end{tabular}


Table 4

Descriptive Statistics and t-test Results for Pre-test and Post-test Scores

\begin{tabular}{|c|c|c|c|c|c|c|c|c|c|c|}
\hline \multirow[b]{2}{*}{ Outcome } & \multicolumn{2}{|c|}{ Pre-test } & \multicolumn{2}{|c|}{ Post-test } & \multicolumn{2}{|c|}{$\begin{array}{l}\text { Post-test - } \\
\text { Pre-test }\end{array}$} & \multirow{2}{*}{$\begin{array}{l}95 \% \\
\text { Confidence } \\
\text { Interval of } \\
\text { Difference }\end{array}$} & \multirow[b]{2}{*}{$\mathrm{t}$} & \multirow[b]{2}{*}{$\mathrm{df}$} & \multirow[b]{2}{*}{$\mathrm{p}$} \\
\hline & $\mathrm{M}$ & $\mathrm{SD}$ & $\mathrm{M}$ & SD & $\mathrm{M}$ & SD & & & & \\
\hline & 24.50 & 7.42 & 46.92 & 7.44 & 22.42 & 11.47 & $\begin{array}{l}10.38, \\
34.45\end{array}$ & 4.788 & 5 & $.005 *$ \\
\hline
\end{tabular}




\section{Table 5}

Descriptive Statistics and Wilcoxon Signed Rank Results for Confidence, Preparedness, and Professional Identity

\begin{tabular}{lll}
\hline Pre-test - Post-test & $Z$ & Asymp. Sig (2-tailed) \\
\hline Confidence & -2.232 & $.026^{*}$ \\
Preparedness & -2.226 & $.026^{*}$ \\
Professional Identity & -1.414 & $.157^{*}$ \\
\hline
\end{tabular}

* significant at alpha level $<.05$ 


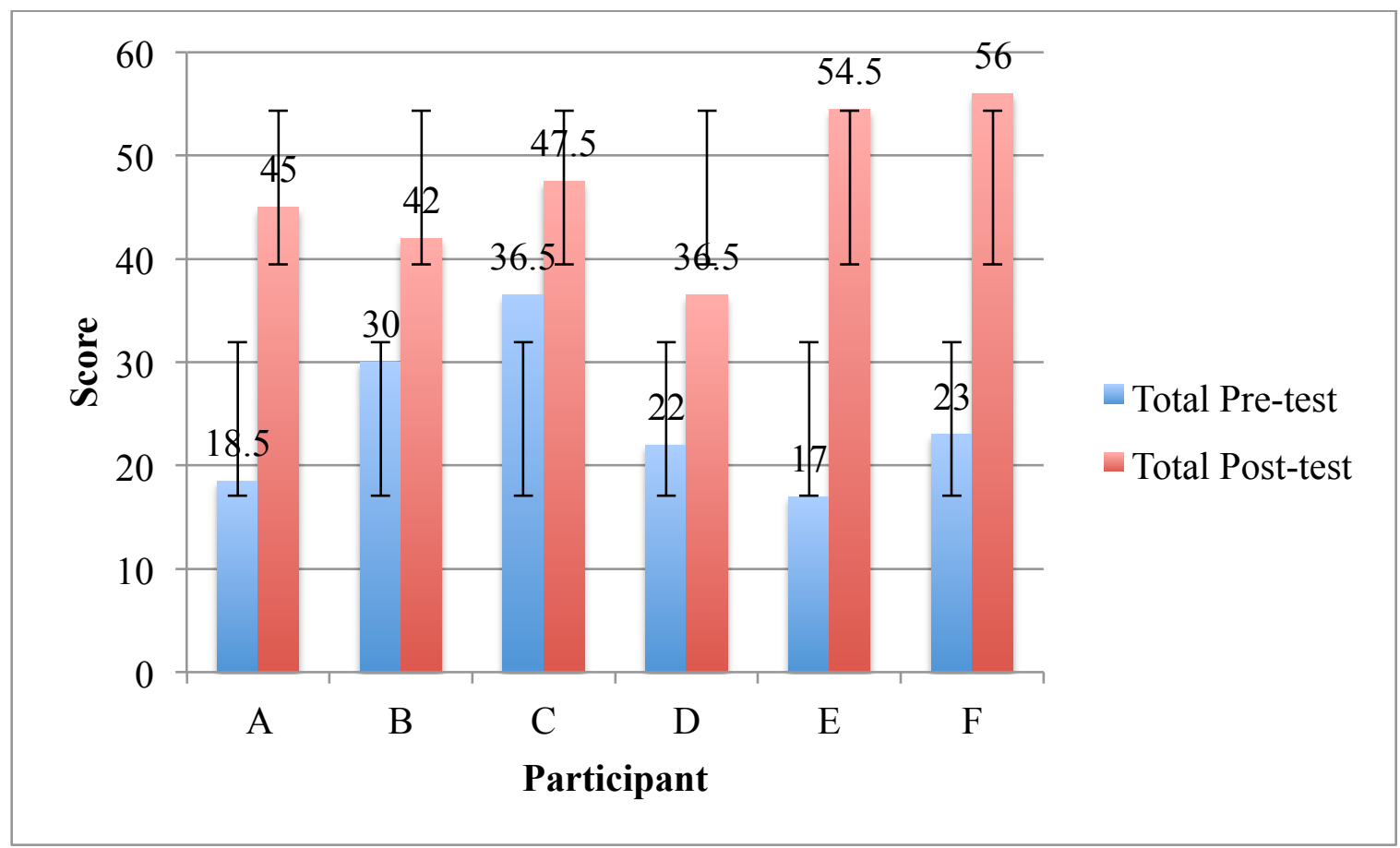

Figure 1. Bar graph depicting participant score totals on pre-test and post-test. Error bars represent one standard deviation above and below the mean. Maximum score was 60 points. 


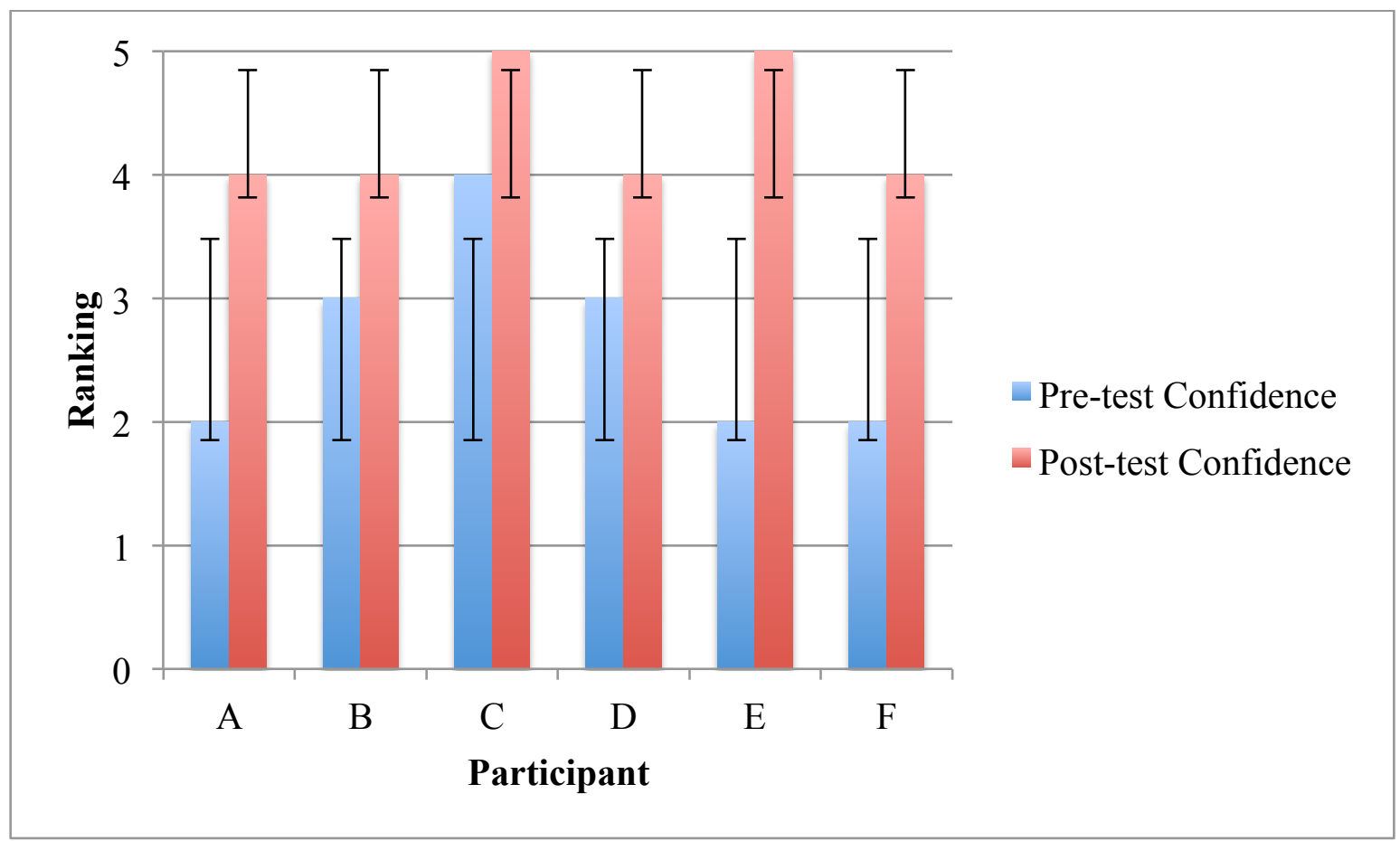

Figure 2. Bar graph depicting participant reports on confidence pre- and post-module completion. Error bars represent one standard deviation above and below the mean. Maximum score was five points. 


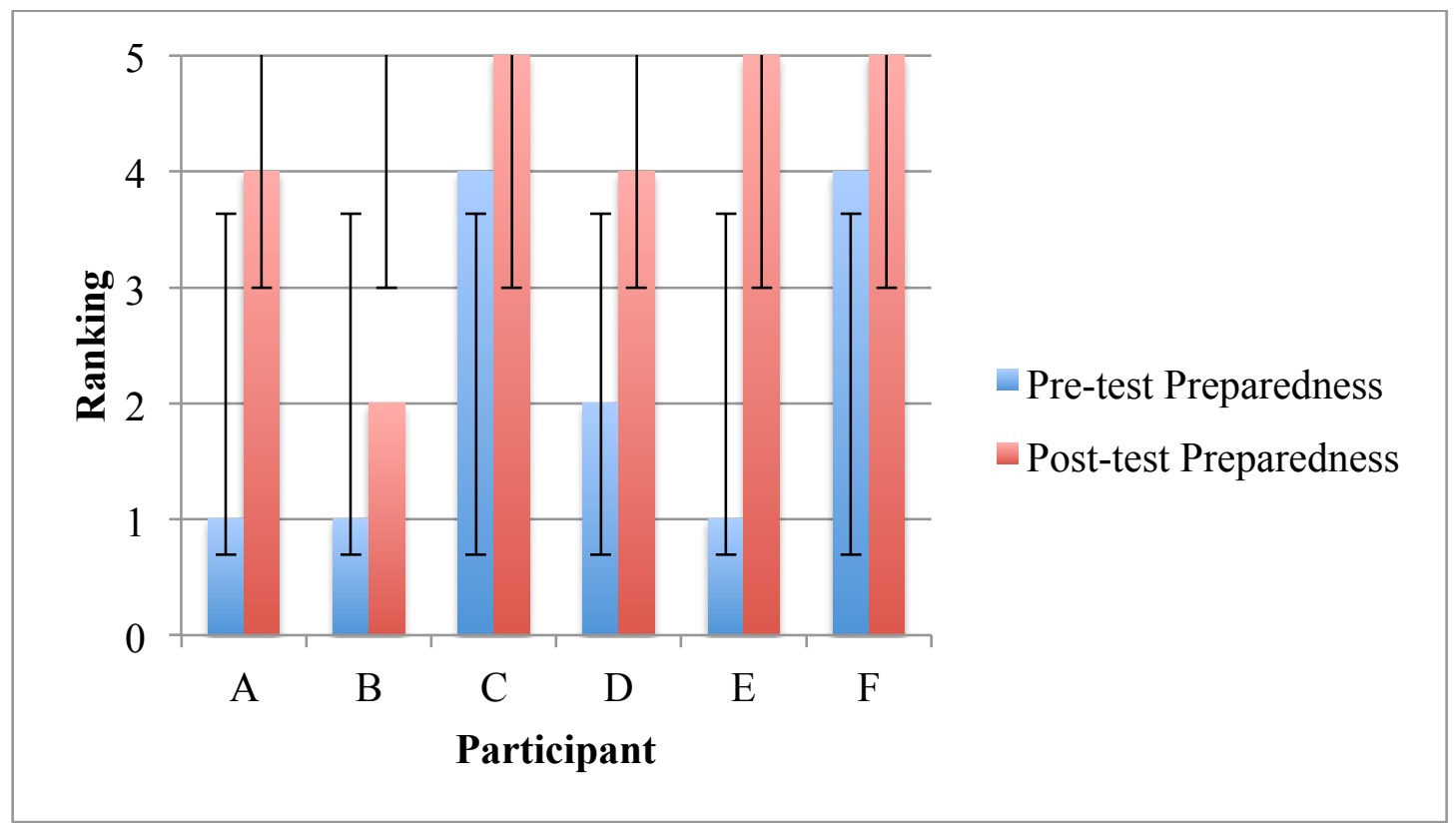

Figure 3. Bar graph depicting participant reports on preparedness pre- and post-module completion. Error bars represent one standard deviation above and below the mean. Maximum score was five points. 


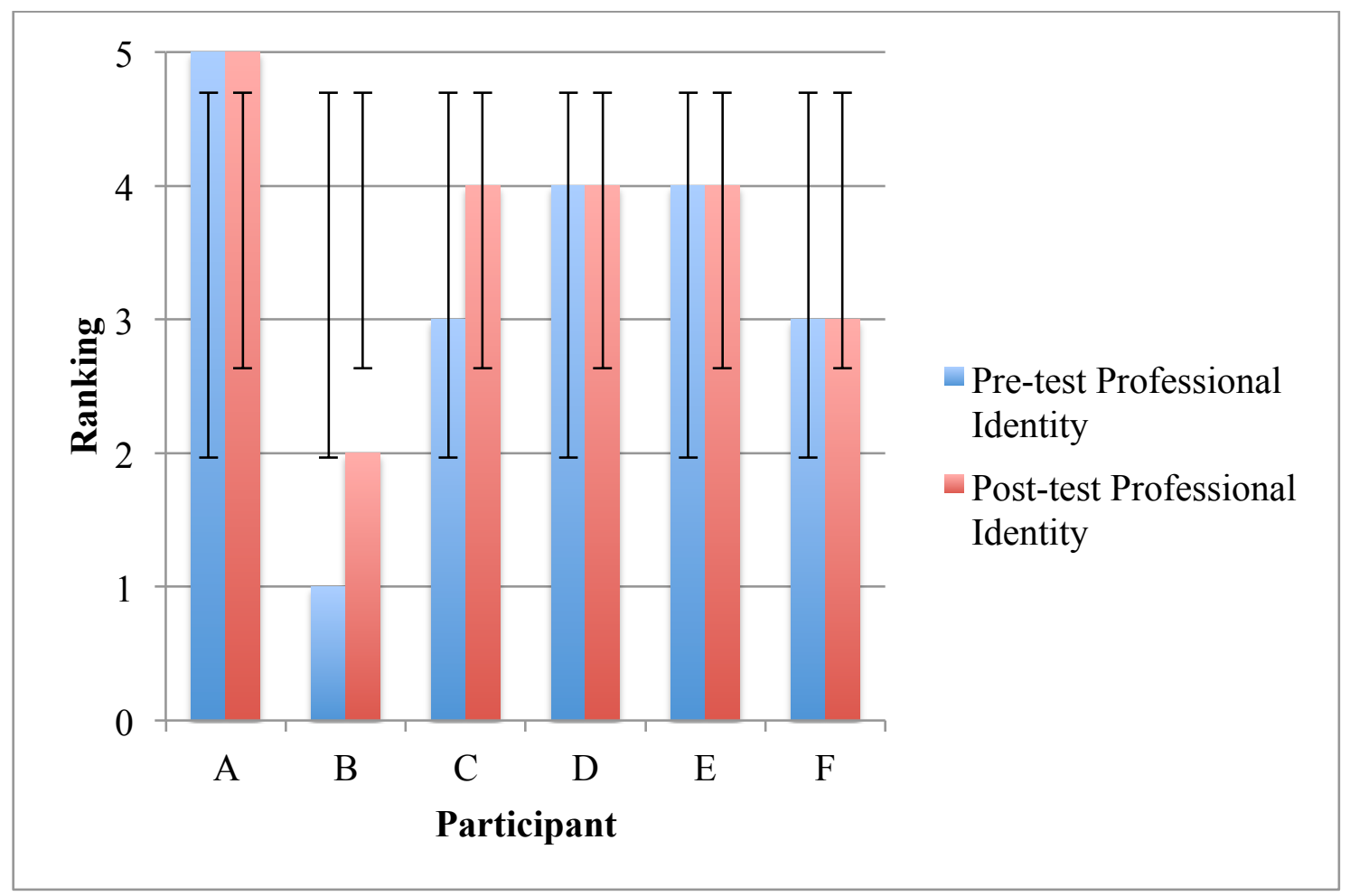

Figure 4. Bar graph depicting participant reports on professional identity pre- and post-module completion. Error bars represent one standard deviation above and below the mean. Maximum score was five points. 
Table 6

Participant Comments on Most Helpful Aspects of Module, Changes for Future Module, and Other Issues

\begin{tabular}{|c|c|c|}
\hline Most helpful aspects & Changes for future module & Other \\
\hline $\begin{array}{l}\text { "The videos of L1 } \\
\text { Spanish-speaker } \\
\text { SLPs. The great } \\
\text { vocabulary really } \\
\text { prepared me for on } \\
\text { the job." }\end{array}$ & "Additional bar for accents" & $\begin{array}{l}\text { "It was a great asset } \\
\text { for us in our } \\
\text { education." }\end{array}$ \\
\hline $\begin{array}{l}\text { "Learning technical } \\
\text { terms I didn't know } \\
\text { in Spanish" }\end{array}$ & $\begin{array}{l}\text { "I think it might be good to talk about how a lot of } \\
\text { parents/clients are not going to understand this } \\
\text { vocab no matter what language you say it in, } \\
\text { because it's so career-specific." }\end{array}$ & $\begin{array}{l}\text { "It was interesting. } \\
\text { I enjoyed it. Thanks } \\
\text { for your hard } \\
\text { work!" }\end{array}$ \\
\hline $\begin{array}{l}\text { "I really liked the } \\
\text { videos. Translating } \\
\text { and saying the } \\
\text { phrases was good } \\
\text { practice." }\end{array}$ & $\begin{array}{l}\text { "There was a lot of vocabulary. It might be a good } \\
\text { idea to reduce the size of the vocabulary lists so } \\
\text { that they include the most salient terminology. } \\
\text { Also this course would have greatly benefited from } \\
\text { a face-to-face component in which students can } \\
\text { practice and role-play. I also feel like sometimes } \\
\text { parents can feel overwhelmed by jargon (both in } \\
\text { English and in Spanish), so it would be good to } \\
\text { also practice explaining the terminology in } \\
\text { everyday language." }\end{array}$ & $\begin{array}{l}\text { "Thank you so } \\
\text { much for providing } \\
\text { us with this } \\
\text { opportunity!" }\end{array}$ \\
\hline $\begin{array}{l}\text { "The vocabulary lists } \\
\text { were very helpful. I } \\
\text { plan on using these } \\
\text { resources in the } \\
\text { future." }\end{array}$ & $\begin{array}{l}\text { "I would add mock conversations for } \\
\text { communicating with both adult [Spanish-] } \\
\text { speaking patients and parents." }\end{array}$ & None \\
\hline $\begin{array}{l}\text { "The vocabulary lists } \\
\text { and videos." }\end{array}$ & "Incorporate videos from a hospital setting." & None \\
\hline $\begin{array}{l}\text { "The vocabulary lists } \\
\text { for each section were } \\
\text { great resources." }\end{array}$ & $\begin{array}{l}\text { "Some of the correct answer choices did not match } \\
\text { the information provided for participants (vocab } \\
\text { lists), which was confusing at times." }\end{array}$ & $\begin{array}{l}\text { "It was frustrating } \\
\text { when the post-test } \\
\text { wouldn't work for } \\
\text { several days." }\end{array}$ \\
\hline
\end{tabular}




\section{CHAPTER 4: DISCUSSION}

\section{Conclusions and Implications}

This study sought to ascertain the effectiveness of a Spanish-language training module by determining the effect of the module on the increase of scores on a vocabulary test, as well as the increase in reported confidence, preparedness, and professional identity. The initial results support overall positive effects of the training module. This was demonstrated both by the increase in scores on the post-test as was initially hypothesized. The reported outcomes in confidence and preparedness also supported the alternate hypothesis, while changes in professional identity did not change as result of the training module.

Although all participants started with varying levels of ability and some common experiences in coursework and cultural encounters, all demonstrated gains in post-test scores and measures of clinical effectiveness. This suggests that individuals from a variety of academic and cultural backgrounds will be able to benefit from practice with technical vocabulary. However, some uniformity in skills allows the participants to participate in higher-proficiency activities, such as translation of longer passages and listening comprehension from a variety of speakers. Furthermore, all students likely experienced gains because they had never encountered the majority of the vocabulary before in Spanish. The limited training opportunities that provide this content are not well-known to graduate students who wish to augment their coursework with Spanish-language skills.

The present study examined the changes in total pre-test and post-test scores. It was noted that participants $\mathrm{B}$ and $\mathrm{C}$, who initially scored higher on the pre-test, did not demonstrate changes as drastic as participants A, E, and F, who initially scored low on the pre-test. This suggests that students who already had some proficiency demonstrated by higher pre-test scores 
did not make gains as great as those who had little proficiency with the vocabulary. For clinicians and students who have limited base vocabulary pertinent to the field, the training module is an effective way of gaining familiarity with many useful terms. However, for individuals who already possess some vocabulary knowledge, the expected gains would not be as great.

Outcomes in confidence and preparedness were shown to be significantly increased after completion of the training module. All participants reported increased feelings of confidence and preparedness when working with Spanish-speaking clients and patients. As Baig and colleagues (2014) reported, self-reported lower Spanish-language proficiency scores resulted in feelings of inadequacy during patient interaction. The outcomes found in this study suggest feelings of inadequacy can be reversed with training opportunities. The present findings replicate studies showing that greater confidence during interactions with patients is reported as a result of training experiences with subsequent increases in both provider and patient satisfaction (Bender, Lawson, Harlan, \& Lopez, 2004; Kritikos, 2003; Mazor, Hampers, Chande, \& Krug, 2002).

There was no difference observed between before and after reports of professional identity. There are some possible explanations for this finding. Only two participants reported an increase in sense of professional identity, both first years in standing. As these participants were still early in their academic study, perhaps they have not yet solidified their professional interests. However, a third first-year participant did not express change in sense of professional identity, so the explanation does not apply to all participants.

This finding highlights an important link to ASHA's demographic profile (2014d) of bilingual members providing services. While only 5\% of ASHA's members self-identify as 
bilingual service providers, those bilingual SLPs and audiologists cannot serve the increasingly diverse general population alone. Monolingual and limited-proficiency SLPs are also working with interpreters or serving other-language and bilingual clients with other strategies in place. Linguistic proficiency therefore may simply be one asset an SLP possesses in serving a variety of clients, rather than being the defining skill that dictates his or her professional specialty.

In open-ended feedback, two participants expressed concern that using technical vocabulary would be overwhelming for some clients and patients. Diamond and Jacobs (2010) suggest that at times specialized technical vocabulary training may contribute to increased misunderstanding in health care settings. This can be due to decreased reliance on professional interpreters and inappropriate use of limited L2 skills, such as failing to explain concepts simply. While the present study demonstrates the improved confidence of SLPs when communicating in Spanish, Diamond and Jacobs would argue that participants should be made aware of how to combine technical vocabulary with explanation in simple language to avoid disparity in understanding. Furthermore, participants should be aware of the importance of consulting with a professional interpreter should the clinician's L2 skills be insufficient. Overall, the SLP's role in facilitating communication with limited English-proficiency patients is increasing across settings and must not be underestimated (Blackstone, Ruschke, Wilson-Stronks, \& Lee, 2011).

\section{Limitations of the Present Study}

While the data demonstrated improvement on pre- and post-test scores for all participants involved, the small sample size does not allow for broader analysis. Further testing with more participants would demonstrate a more convincing application to the general population of SLPs. The small sample size in this case was due to limited interest within the graduate students in the program. 
Ideally, this study would contain a complete follow-up data point using the same assessment to determine if participants maintained vocabulary gains well beyond the completion of the module. However, due to the fact that some participants graduated, this was not possible for this trial. Other informal measures of participant satisfaction such as interviews or questionnaires might have addressed the carryover of technical vocabulary in clinical encounters in the long-term after module completion. Yet to promote use of the module materials as references in future work with Spanish-speaking clients, participants were able to download vocabulary lists and other resources.

Participants expressed in follow-up comments that module would be more effective had a face-to-face component or mock conversation been incorporated into activities. An interpersonal element would be a valuable addition to the module contents for participants to practice with the technical vocabulary, thus promoting generalization of skills to other environments. While the exclusively online format of the module was a drawback for this participant, it was also a strength for accessibility and convenience. Including diverse speakers in listening opportunities was also proposed in follow-up comments as a possibility for increasing generalization of vocabulary skills to different dialects or accents.

\section{Directions for Future Study}

The present study would benefit from possible expansion and thorough consideration of module contents. Future iterations of the module might include combining technical vocabulary study with activities promoting cultural competence in the field. Incorporating concepts from the field cultural competence specific to Spanish-speaking clients would allow participants to develop a more specialized understanding of culture and behaviors that may affect assessment and intervention. 
Another possible direction for module construction is further developing case studybased activities so that participants can encounter vocabulary in the most naturalistic context. While presentation of vocabulary in lists is not highly naturalistic, some participants did report that they found the list format helpful and plan to use the lists in the future. Participant reports also expressed that vocabulary from other areas within speech-language pathology should be incorporate for those SLPs working with adult populations.

Given trends in population, more monolingual SLPs will be coming into contact with Spanish-speakers in all clinical settings (Pew, 2013). A beginner-level version of the module incorporating more basic concepts from Spanish-language education would help to serve the bilingual population that will continue to grow in the upcoming decades. Recognizing basic structures and everyday vocabulary would not only aid the monolingual SLP to develop comprehension skills and expressive ability for communication with Spanish-speaking clients and patients, but also increase confidence levels of SLPs assessing and treating bilingual individuals (Kritikos, 2003). 


\section{CHAPTER 5: REFERENCES}

American Speech-Language-Hearing Association. (2007). Scope of practice in speech-language pathology [Scope of Practice]. Retrieved January 20, 2014 from www.asha.org/policy. doi:10.1044/policy.SP2007-00283

American Speech-Language-Hearing Association. (2014a). Bilingual service delivery. Retrieved January 20, 2014, from http://www.asha.org/PRPSpecificTopic.aspx?folderid=8589935 $225 \&$ section $=$ Overview

American Speech-Language-Hearing Association. (2014b). Historically black colleges and universities and multicultural/bilingual emphasis programs. Retrieved January 20, 2014, from http://www.asha.org/practice/multicultural/opportunities/hbi.htm

American Speech-Language-Hearing Association. (2014c). MMI foundational courses: Sample syllabi [Communication disorders in multicultural populations]. Retrieved February 17, 2015, from http://www.asha.org/practice/multicultural/faculty/cdinmd.htm

American Speech-Language-Hearing Association. (2014d). Demographic profile of ASHA members providing bilingual services. Retrieved from http://www.asha.org/uploaded Files/Demographic-Profile-Bilingual-Spanish-Service-Members.pdf

American Speech-Language-Hearing Association. (2010). Code of ethics [Ethics]. Retrieved from www.asha.org/policy.

Baig, A., Benitez, A., Locklin, C., Campbell, A., Schaefer, C., Heuer, L., Lee, S., Solomon, M., Quinn, M., Burnet, D., \& Chin, M. (2014). Community health center provider and staff's Spanish language ability and cultural awareness. Journal of Health Care for the Poor and Underserved, 25, 527-545. doi:10.1353/hpu.2014.0086 
Bender, D.E., Clawson, M., Harlan, C., \& Lopez, R. (2004). Improving access for Latino immigrants: Evaluation of language training adapted to the needs of health professionals. Journal of Immigrant Health, 6(4), 197-209.

Bialystok, E. (2001). Bilingualism in development. New York, NY: Cambridge University Press. Bilingual. (n.d.). In Merriam-Webster.com. Retrieved May 8, 2011, from http://www.merriamwebster.com/dictionary/bilingual

Blackstone, S., Ruschke, K., Wilson-Stronks, A., \& Lee, C. (2011). Converging communication vulnerabilities in health care: An emerging role for speech-language pathologists and audiologists. SIG 14 Perspectives on Communication Disorders and Sciences in Culturally and Linguistically Diverse (CLD) Populations, 18, 3-11. doi:

$10.1044 / \operatorname{cds} 18.1 .3$

Bloomfield, L. (1933) Language. Holt: New York.

Bloom, M., Timmerman, G.M., \& Sands, D. (2006). Developing a course to teach Spanish for health care professionals. Educational Innovations, 45(7), 271-274.

Castaño, M.T., Biever, J., González, C., \& Anderson, K. (2007). Challenges of providing mental health services in Spanish. Professional Psychology: Research and Practice, 38, 667673. doi: 10.1037/0735-7028.38.6.667

Cobb, F.M., Perez-Brown, D.,\& Owens, T.H. (2011). Incorporating the Spanish language in a health sciences curriculum. Journal of Best Practices in Health Professions Diversity: Research, Education, and Policy, 4, 695-702.

Cummins, J. (1979). Cognitive/academic language proficiency, linguistic interdependence, the optimum age question and some other matters. Working Papers on Bilingualism, 19, 121 129. 
Diamond, L. \& Jacobs, E. (2010). Let's not contribute to disparities: The best method for teaching clinicians how to overcome language barriers to health care. Journal of General Internal Medicine, 25, 189-193. doi: 10.1007/s11606-009-1201-8

Diebold, Jr. A. R., (1961) Incipient bilingualism. Language, 37, 97-112.

Dinkins, M.M. \& Scolaro, K.L. (2012). A Spanish language module in a first-year pharmaceutical care laboratory course. American Journal of Pharmaceutical Education, 76, 70. doi: 10.5688/ajpe76470

Ebert, K., Kohnert, K., Pham, G., Disher, J.R., \& Payestah, B. (2014). Three treatments for bilingual children with primary language impairment: Examining cross-linguistic and cross-domain effects. Journal of Speech, Language, and Hearing Research, 57, 172-186. doi: 10.1044/1092-4388(2013/12-0388)

Esckelson, D. M. \& Morales, A. A. (1998). Spanish phrasing for SLP's. Ann Arbor, MI: Language Pathways.

Fan, M.Y. (2003). Frequency of use, perceived usefulness, and actual usefulness of second language vocabulary strategies: A study of Hong Kong learners. Modern Language Journal, 87, 222-241.

Grosjean, F. (1989). Neurolinguists, beware! The bilingual is not two monolinguals in one person. Brain and Language, 36, 3-15.

Hammer, C.S., Detwiler, J.S., Detwiler, J., Blood, G., \& Qualls, C.D. (2004). Speech-language pathologists' training and confidence in serving Spanish-English bilingual children. Journal of Communication Disorders, 37, 91-108. doi:10.1016/j.jcomdis.2003.07.002

Haugen, E. (1969). The Norwegian language in America; a study in bilingual behavior [by] Einar Haugen. Bloomington, Indiana University Press [1969]. 
Hummel, K.M. (2010). Translation and short-term L2 vocabulary retention: Hindrance or help?. Language Teaching Research, 14(1), 61-74. doi: 10.1177/1362168809346497

Kay-Raining Bird, E., Cleave, P., Trudeau, N., Thordardottir, E., Sutton, A., \& Thorpe, A. (2005). The language abilities of bilingual children with Down syndrome. American Journal of Speech-Language Pathology, 14, 187-199. doi:10.1044/1058-0360(2005/019)

Kohnert, K., Yim, D., Nett, K., Kan, P.F., \& Duran, L. (2005). Intervention with linguistically diverse preschool children: A focus on developing home language(s). Language, Speech, and Hearing Services in Schools, 36, 251-263. doi: 0161-1461/05/3603-0251

Kritikos, E.P. (2003). Speech-language pathologists' beliefs about language assessment of bilingual/bicultural individuals. American Journal of Speech-Language Pathology, 12, 73-91. doi: 1058-0360/03/1201-0073

Lawson, M.J. \& Hogben, D. (1996) The vocabulary-learning strategies of foreign-language students. Language Learning, 46 (1), 101-135.

Matelliano, M. \& Stone, J. (2014). Cultural competence education in university rehabilitation programs. Journal of Cultural Diversity, 21, 112-118.

Mazor, S., Hampers, L., Chande, V., \& Krug, S. (2002). Teaching Spanish to pediatric emergency physicians. Archives of Pediatric and Adolescent Medicine, 156, 693-695.

Paradis, J., Crago, M., Genesee, F., \& Rice, M. (2003). French-English bilingual children with SLI: How do they compare with their monolingual peers? Journal of Speech, Language, and Hearing Research, 46, 113-127. doi: 1092-4388/03/4601-0113

Pew Research Center. (2011). Characteristics of the population in North Carolina, by race, ethnicity, and nativity: 2011. Retrieved January 20, 2014 http://www.pewhispanic.org/files/states/pdf/NC_11.pdf 
Pew Research Center. (2013). Spanish is the most spoken non-English language in U.S. homes, even among non-Hispanics. Retrieved January 20, 2014 http://www.pewresearch.org/fact-tank/2013/08/13/spanish-is-the-most-spoken-nonenglish-language-in-u-s-homes-even-among-non-hispanics/

Pew Research Center. (2014b). Demographic Profile of Hispanics in North Carolina, 2011. Retrieved January 20, 2014 from http://www.pewhispanic.org/states/state/nc/

Pew Research Center. (2014a). The U.S. Hispanic population has increased sixfold since 1970. Retrieved January 20, 2014 from http://www.pewresearch.org/fact-tank/2014/02/26/theu-s-hispanic-population-has-increased-sixfold-since-1970/

Pham, G., Kohnert, K., \& Mann, D. (2011). Addressing clinician-client mismatch: A preliminary intervention study with a bilingual Vietnamese-English preschooler. Language, Speech, and Hearing Services in Schools, 42, 408-422. doi: 10.1044/0161-1461(2011/10-0073

Stewart, S.R. \& Gonzalez, L.S. (2002). Serving a diverse population: The role of speechlanguage pathology professional preparation programs. Journal of Allied Health, 31(4), 204-216.

Stone, M., Patel, N., Amin, S., Daly, H., Carey, M., Khunti, K., Davies, M., \& Dogra, N. (2013). Developing and initially evaluating two training modules for healthcare providers, designed to enhance cultural diversity awareness and cultural competence in diabetes. Diversity and Equality in Health and Care, 10, 177-184.

U.S. Census Bureau. (2010). State \& county Quickfacts: North Carolina. Retrieved January 20, 2014, from http:/quickfacts.census.gov/qfd/states/37000.html 
Verdinelli, S. \& Biever, J. (2009). Spanish-English bilingual psychotherapists: Personal and professional language development and use. Cultural Diversity and Ethnic Minority Psychology, 15, 230-242. doi: 10.1037/a0015111 


\section{APPENDIX A}

\section{CONSENT FORM}

\section{Informed Consent for Participation}

Title of Study: Effect of Spanish-Language Training Module on Technical Vocabulary Acquisition

You have been invited to participate in a study conducted by Western Carolina University due to your interest and experience in the Spanish language and Communication Sciences and Disorders (CSD). The study will help to determine if Spanish-language training modules are useful for vocabulary learning in CSD students who wish to work with Spanish-speaking clients in their careers. This pilot version of the module may later be expanded and offered to anyone interested in developing this skill.

The module will be available during a six-week period with the recommendation that students spend 2-3 hours each week studying one of the four content areas and allowing one hour for completion of the pre- and post-tests. If you choose to participate, you will be asked to take a pre-test on Spanish-English vocabulary via Blackboard followed by a series of training activities. Following completion of the training modules, you will complete a post-test similar to the pretest measure to quantify your learning and skill development in response to the module. Only your responses on the pre- and post-test will be recorded to track your improvement. To avoid influencing the results, please do not self-study on these topics between sessions, and do not use "cheat sheets" or notes on the pre-or post-tests. If you choose to participate, you will write and sign an honor code that agrees you will not use resources on the tests in this module or self-study with materials other than those included in the module.

Your participation is completely voluntary and confidential, and you will be assigned a participant code. Your performance may be discussed in the publication and presentation of the data obtained; however, all identifying information will be removed. Your participation will not have an impact on your grade point average or standing in the Communication Sciences \& Disorders (CSD) department. You may withdraw from the study at any time without consequence.

No risks are anticipated to the participants involved in this study. Benefits to you may include learning new Spanish-language vocabulary associated with CSD, as well as receiving the certificate of completion.

If you have any questions about this study, please contact Claire Wofford at mcwofford1@catamount.wcu.edu or 336-403-0462. If you have any questions or concerns about your rights as a study participant, contact the IRB at IRB@wcu.edu or at 828-227-7212. Your signature below indicates that you understand the information above and willingly agree to participate. 
Printed Name 
APPENDIX B

INTAKE QUESTIONNAIRE

Spanish-Language Module Intake Questionnaire

Name:

DOB:

Age:

Advisor:

Email:

92-number:

Username:

Please circle.

Current academic standing: Undergraduate $-\mathrm{Fr} / \mathrm{Soph} / \mathrm{Jr} / \mathrm{Sr}$ Graduate $-1^{\text {st }}$ year $/ 2^{\text {nd }}$ year

Department: $\quad$ CSD Other

Please describe your academic experience with Spanish.

Please mark the highest-level of Spanish-language coursework you have completed.

High school

Undergraduate-Introductory courses (Introduction to Spanish, Basic Spanish, etc.)

Undergraduate-Intermediate (Grammar/Composition, Conversation, Intro to Literature, etc.)

Undergraduate-Advanced (Literature courses, Special topics courses, etc.)

Community college

Other (please specify):

Please describe your cultural experience with Spanish.

Please mark the following Spanish-language cultural experiences that apply to you.

I have a family member who speaks Spanish to me.

I was raised speaking Spanish in my home.

I spent time in a Spanish-speaking country. If yes, how long?

I lived in a Spanish-speaking country.

I studied abroad in a Spanish-speaking country.

I worked in a setting that required me to speak Spanish with my coworkers.

Other (please specify): 
Why do you want to complete this course? 


\section{APPENDIX C}

\section{HONOR CODE SUPPLEMENT}

\section{Consent to Honor Code for Participation}

Title of Study: Effect of Spanish-Language Training Module on Technical Vocabulary Acquisition

Honor Code: Please sign and print your name and write the date to consent. If you choose not to consent, you will not be included in the study.

I will not use notes, print-outs, dictionaries, or other external resources on the tests in this module. I will not study the terminology outside of the module activities.

Signature

Printed Name
Date 


\section{APPENDIX D}

\section{PRE-TEST/POST-TEST}

Pre-Test

\begin{tabular}{|c|c|}
\hline aspiration & aspiración; la aspiración \\
\hline blends & combinaciones; las combinaciones \\
\hline final consonant deletion & $\begin{array}{l}\text { eliminación (f) de la consonante final; } \\
\text { la eliminación de la consonante final }\end{array}$ \\
\hline hard palate & $\begin{array}{l}\text { paladar duro; el paladar duro; } \\
\text { paladar óseo; el paladar óseo }\end{array}$ \\
\hline phonological processes & $\begin{array}{l}\text { procesos fonológicos; } \\
\text { los procesos fonológicos }\end{array}$ \\
\hline speech-language pathologist (USA) & $\begin{array}{l}\text { patólogo(a) del habla y lenguaje; } \\
\text { el patólogo del habla y lenguaje; } \\
\text { la patóloga del habla y lenguaje }\end{array}$ \\
\hline speech-language pathologist (USA) & $\begin{array}{l}\text { terapista del habla; el terapista del habla; } \\
\text { la terapista del habla }\end{array}$ \\
\hline speech-language pathologist (Spain) & logopeda; el logopeda; la logopeda \\
\hline speech-language pathologist (Latin America & $\begin{array}{l}\text { a)fonoaudiólogo(a); el fonoaudiólogo; } \\
\text { la fonoaudióloga }\end{array}$ \\
\hline speech-language pathology (USA) & $\begin{array}{l}\text { patología del habla; la patología del } \\
\text { habla; terápia del habla; } \\
\text { la terápia del habla }\end{array}$ \\
\hline speech-language pathology (Spain) & logopedia; la logopedia \\
\hline speech-language pathology (Latin America) & fonoaudiología; la fonoaudiología \\
\hline circumlocution & circunlocución; la circunlocución \\
\hline stutter (v) & tartamudear \\
\hline triggers (n) & provocaciones; las provocaciones \\
\hline rate of speech & paso del habla; el paso del habla \\
\hline cleft palate & $\begin{array}{l}\text { fisura del paladar; la fisura del paladar; } \\
\text { paladar hendido; el paladar hendido }\end{array}$ \\
\hline hoarseness & ronquera; la ronquera \\
\hline hypernasality & hipernasalidad; la hipernasalidad \\
\hline velopharyngeal & velofaríngeo(a) \\
\hline wheeze (v) & resollar \\
\hline augmentative communication device & $\begin{array}{l}\text { aparato aumentativo de comunicación; } \\
\text { el aparato aumentativo de comunicación }\end{array}$ \\
\hline early intervention & $\begin{array}{l}\text { intervención temprana; la intervención } \\
\text { temprana }\end{array}$ \\
\hline learning disability & incapacidad de aprendizaje; \\
\hline
\end{tabular}


morphological endings

word retrieval la incapacidad de aprendizaje

terminaciones morfológicas;

las terminaciones morfológicas

recuperación de las palabras;

la recuperación de las palabras

II. Eliga la(s) palabra(s) adecuada(s) para completar la oración. (Choose the appropriate word to complete the sentence.)

1. es recomendada para cualquier niño(a) que no ha aprendido a hablar para que la gente entienda lo que está diciendo o que atrae la atención negativa a sí mismo(a) con los hábitos anormales del habla que tiene causas físicas que le previenen o impiden los intentos de hablar.
a. La terapia del habla*
b. La cirugía
c. La retroalimentación
d. Ninguno

2. es un impedimiento del habla que afecta el control de los movimientos de los músculos del habla (la lengua, los labios, el paladar), previniendo o limitando la producción del habla normal.
a. El abuso vocal
b. La apraxia del desarollo *
c. La afasia de la niñez
d. Ninguno

3. Su niño(a) tiene problemas recordando lo que oye. Esto se llama un problema de
a. la memoria auditiva *
b. el autismo
c. la recuperación de las palabras
d. Ninguno

4. Sus sentimientos y su actitud hacia grado sus sentimientos y sus reacciones hacia el niño/la niña. de su niño(a) afectarán en algún
a. las vacilaciones
b. el tartamudeo*
c. el manejo
d. Ninguno 
5. Su niño(a) sera enseñado(a) el uso de la voz en una manera que no la irritará. Algunos alta, llorando, son listados para su información: gritando, hablando en voz
a. abuso vocal; gritando; fisura del labio
b. abusos vocales; tosiendo; rigidez
c. abusos vocales; gritando; carraspeando la garganta *
d. Ninguno

III. Conteste las preguntas sobre el video. (Answer the questions about the video.) See videos "Phonological Processes", "Language", "Voice" for corresponding videos. Links also available at:

"Phonological Processes":

http://fpamediaserver.wcu.edu/ mcwofford/Phonological_Processes.html "Language"

http://fpamediaserver.wcu.edu/ mowofford/Language.html

"Voice":

http://fpamediaserver.wcu.edu/ mowofford/Voice.html

1. ¿De los siguientes procesos fonológicos cuál de ellos está demonstrando el cliente?

a. La supresión de la consonante final

b. La apraxia del desarollo

c. La eliminación de la consonante incial

d. Ninguno *

2. ¿Qué va a hacer la terapista para observar el lenguaje del cliente?

a. Tomar un ejemplo del lenguaje *

b. Observar los hitos del niño

c. Hablar del lenguaje expresivo

d. Ninguno

3. ¿Cuál no es una forma de abuso vocal según el vídeo?

a. Carraspear la garganta

b. Toser

c. Susurrar *

d. Ninguno

IV. Cómo se diría...?

Traduzca lo siguiente. Grabe su respuesta y súbala. (Translate the following. Record your answer and upload it.)

1. Your child speaks with a lisp because he says the "s" and " $z$ " sounds incorrectly. He has no problems with his speech mechanism. Speech therapy is recommended. 
Su niño(a) habla con un ceceo porque dice los sonidos " $s$ " y " $z$ " incorrectamente. No tiene problemas con el mecanismo del habla. Se recomiende la terapia del habla.

3 points

ceceo

el mecanismo del habla

speech therapy

2. Ask the parent the following questions about his/her child:

Pregunte al padre sobre su hijo(a).

Does your child take turns in conversations at home?

Does your child imitate people in the environment?

Does your child prefer independent play?

Su niño toma turnos en conversaciones en casa?

Imita su niño a otras personas en el ambiente?

Prefiere su niño el juego independiente?

4 points

tomar turnos

imitar

ambiente

el juego independiente

3. If your child asks you about his fluency, say that everyone has trouble at times talking about their feelings and that we often hesitate and repeat words.

Si su niño le pregunta sobre su fluidez, dígale que todos tenemos problemas a veces cuando hablamos de nuestros sentimientos y que muchas veces vacilamos y repetimos las palabras.

2 points

fluidez

vacilar

4. Your child's test results indicate that she has a speech delay along with her language delay.

Los resultados de las pruebas de su niña indican que ella tiene un retraso del habla junto al restraso del lenguaje.

3 points

retraso

habla

lenguaje 
5. To reduce vocal nodules and prevent the formation of more nodules or polyps later on, the therapy goals will be to reduce vocal abuse and to lower the pitch level.

Para reducir los nódulos vocales y prevenir la formación de más nódulos y pólipos más tarde, las metas de terapia seran reducir el abuso vocal y bajar el nivel del tono.
4 points
nódulos vocales
pólipos
el abuso vocal
el tono 


\section{APPENDIX E}

\section{EXIT SURVEY}

Exit Survey

Spanish-Language Training Module

NAME:

\section{Confidence}

On a scale from 1-5 how confident did you feel about working with Spanish-speaking patients or clients BEFORE completing the module?

\begin{tabular}{|c|c|c|c|}
\hline & 2 & $\begin{array}{l}3 \\
\text { Neutral }\end{array}$ & \multirow{2}{*}{$\begin{array}{l}4 \\
\text { Somewhat }\end{array}$} \\
\hline & $\begin{array}{l}\text { Somewhat } \\
\text { not confident }\end{array}$ & Neutral & \\
\hline
\end{tabular}

On a scale from 1-5 how confident did you feel about working with Spanish-speaking patients or clients AFTER completing the module?

\begin{tabular}{|c|c|c|c|}
\hline$t$ at al & $\begin{array}{c}2 \\
\text { Somewl }\end{array}$ & & 4 \\
\hline $\begin{array}{l}\text { Not at all } \\
\text { confident }\end{array}$ & $\begin{array}{l}\text { Somewhat } \\
\text { not confident }\end{array}$ & & $\begin{array}{l}\text { Somewhat } \\
\text { confident }\end{array}$ \\
\hline
\end{tabular}

\section{Preparedness}

On a scale from 1-5 how prepared did you feel to work with Spanish-speaking patients or clients BEFORE completing the module?

$\begin{array}{lcccc}1 & 2 & 3 & 4 & 5 \\ \begin{array}{l}\text { Not at all } \\ \text { prepared }\end{array} & \begin{array}{c}\text { Somewhat } \\ \text { not prepared }\end{array} & \text { Neutral } & \begin{array}{l}\text { Somewhat } \\ \text { prepared }\end{array} & \begin{array}{l}\text { Extremely } \\ \text { prepared }\end{array}\end{array}$

On a scale from 1-5 how prepared did you feel to work with Spanish-speaking patients or clients AFTER completing the module?

$\begin{array}{lcccc}1 & 2 & 3 & 4 & 5 \\ \begin{array}{l}\text { Not at all } \\ \text { prepared }\end{array} & \begin{array}{c}\text { Somewhat } \\ \text { not prepared }\end{array} & \text { Neutral } & \begin{array}{l}\text { Somewhat } \\ \text { prepared }\end{array} & \begin{array}{l}\text { Extremely } \\ \text { prepared }\end{array}\end{array}$

\section{Professional Identity}

On a scale from 1-5 how developed was your sense of professional identity BEFORE completing the module?

$\begin{array}{lcccc}1 & 2 & 3 & 4 & 5 \\ \begin{array}{l}\text { Not at all } \\ \text { developed }\end{array} & \begin{array}{c}\text { Somewhat } \\ \text { not developed }\end{array} & \text { Neutral } & \begin{array}{c}\text { Somewhat } \\ \text { developed }\end{array} & \begin{array}{c}\text { Extremely } \\ \text { developed }\end{array}\end{array}$


On a scale from 1-5 how developed was your sense of professional identity AFTER completing the module?

$\begin{array}{lcccc}1 & 2 & 3 & 4 & 5 \\ \begin{array}{l}\text { Not at all } \\ \text { developed }\end{array} & \begin{array}{c}\text { Somewhat } \\ \text { not developed }\end{array} & \text { Neutral } & \begin{array}{c}\text { Somewhat } \\ \text { developed }\end{array} & \begin{array}{c}\text { Extremely } \\ \text { developed }\end{array}\end{array}$

\section{Effectiveness}

On a scale from 1-5 how effective do you feel this module was in training the technical vocabulary?

1

Not at all

effective
2

Somewhat
not effective
3

Neutral
4

Somewhat effective
5

Extremely

effective

What aspects of the module were most helpful?

What changes would you make to the module for future participants?

What other comments do you have regarding the module? 